\title{
Informational Environments: Organizational Contexts of Online Information Use
}

\author{
Roberta Lamb \\ Manoa, College of Business Administration, Information Technology Management, University of Hawaii, \\ Honolulu, HI 96822. E-mail: lamb@cba.hawaii.edu \\ John Leslie King \\ School of Information, University of Michigan, Ann Arbor, MI 48109. E-mail: jking@umich.edu \\ Rob Kling \\ Center for Social Informatics, School of Library and Information Science, Indiana University, Bloomington, \\ IN 47405. E-mail: kling@indiana.edu
}

\begin{abstract}
Before the Web, the story of online information services was largely one of over-estimates and unmet expectations. This study examines sustained use and non-use of online services within organizations in a way that overcomes limitations of the traditional approaches that repeatedly led to exuberant usage projections. By adopting an open-systems view, we see that firms in highly technical and highly institutional environments have many more incentives to gather data and go online than do firms in low-tech, unregulated industries. But firms make important choices about partnering and outsourcing that can shift informational activities across organizational boundaries. Our analysis focuses on the informational environments of firms in three industries: law, real estate and biotech/pharmaceuticals. This environmental model provides richer conceptualizations about the use of information and communication technologies, including Internet technologies, and better projections about future use. In support of our analysis, we briefly discuss insights from an ongoing intranets study informed by an informational environments perspective.
\end{abstract}

\section{Before the Web, There Was Online. . .}

When someone says "online" we think about Internet technologies, like the Web, intranets and extranets. And when we think about what motivates people to use these new information and communication technologies (ICTs), we often focus on the needs, capabilities and preferences of an individual. However, much of what we "know" about

Received January 25, 2002; revised July 23, 2002; accepted July 23, 2002.

(C) 2003 Wiley Periodicals, Inc. going online we learned by studying the use of online services. And even though online service use research was frequently conducted by studying the activities of isolated individuals gathering information for personal use, actual use of online services most often occurred within complex organizations. So what do we really "know" about going online? What theories have we used to explain the sustained use and non-use of online services, and can these be extended to explain the use of other organizational ICTs, like intranets?

Over the past 25 years, information researchers have compiled an impressive collection of studies that examine the use of online information resources from an individual perspective (Bellardo, 1985; Borgman, 1989; Newby et al., 1991; Morris, 1994; Sugar, 1995.) These studies answer some important questions about how and why people go online. We know, for example, that having resources that are easy to use and close at hand, or simply being aware that a resource exists, affects people's choices. Unfortunately for vendors of online information, these understandings could not be scaled up to provide reliable estimates of organizational online use. In similarly focused studies of organizational individuals, researchers concluded that firms vary widely in their online use, and that this variation was not well understood ${ }^{1}$ (Culnan, 1985; Aumente, 1987; Nicholas et al., 1988; Williams, 1985; Williams, 1995.) Furthermore, Baldwin and Rice (1997) found that among securities analysts, individual characteristics have little influence on information source choice. Although inconclusive and con-

\footnotetext{
${ }^{1}$ Vendor marketing surveys yielded the same inconclusive results (personal communication with Knight-Ridder executive).
} 
tradictory findings seem to undermine the value of early online research, we believe that studies of past online use can tell us a lot about current and future online useparticularly about the organizationally constrained use of Internet technologies (like intranets and extranets)—with a shift in theoretical basis toward richly contextualized, open systems.

In this paper we describe a study of twenty-six California firms that was conducted just as the use of online services had reached a zenith, as organizational use of the Internet was becoming widespread, and as the first intranets were coming into use (1995-1997). Our research goal was to characterize the situated use of online services across a range of organizations and industries, and to focus on environmental aspects that might explain variations is use. This variation had concerned academic researchers, as well as online industry market analysts, for the previous decade. To tackle the problem, we employed an integrated set of qualitative research methods to collect and analyze study data, including theoretical sampling, in-depth semi-structured interviewing, and concurrent analysis of coded transcripts. Interestingly, we found that some organizations make much greater use of online information, and that has as much to do with external factors as with any internal decisions of the firms' managers or with aggregate choices by the firm's information workers. Institutional demands, such as disclosure mandates and regulatory agency approval requirements, motivate intensive data gathering activities. And interorganizational interactions with clients, vendors and competitors further shape online use. Our analysis and discussion of these findings suggests that institutional theory can help us describe the informational environments of organizations that use online services, and that by characterizing informational environments we can understand the infrastructures of current and future ICT use. We conclude this paper with a brief description and some promising preliminary results from an ongoing intranet study (1998 to the present) that tests this theoretical extension.

\section{Traditional Understandings of Online Use}

Until the World Wide Web became widely and freely available, the online story was largely about failed expectations. Originally, both business and individual consumers were expected to benefit enormously from the availability of online information. Early expectations about the widespread use of online technologies were spurred by statistical evidence of an expanding information service sector and visions of an Information Society (Bell, 1973; Porat and Rubin, 1977; Cooper, 1983.) Some academic theorists and writers in the popular business press had claimed that an investment in online services and electronic information resources could bolster an organization's service-sector productivity as well as its industry position by making critical, decision-making information more readily available to managers and information workers. They encouraged strategic use of information and electronic media as a way to gain competitive advantage (Porter and Millar, 1985; Marchand and Horton, 1986; Applegate et al., 1996.) Yet, despite general enthusiasm for online technologies, use fell short of expectations (Eng, 1995; Williams, 1985; Williams, 1995.) In the early 1980's, several firms cooperated on joint videotext ventures, expecting a consumer rush. In France, the government-supported Minitel system was a raging success, but in the U.S. similar commercial efforts failed miserably (Cats-Baril and Jelassi, 1994.) The commercial online information services of that era were curated collections of indexed electronic databases with supporting distribution services. Online service vendors traditionally provided feefor-service modem access to mainframes containing these databases of strategic business, scientific, legal and financial information. Initially, the services were entirely text-based. Now most online providers supplement their mainframe offerings with multimedia-enhanced CD-ROM products. They have also provided additional access points via consumer utilities like CompuServe and America OnLine, and the World Wide Web. Critics continue to complain that the user interfaces of many online services are cumbersome, and hard to use; and that pricing structures are confusing and expensive. Despite these technical and economic difficulties, however, some organizations still use them intensively; while others have only ever used them very little or not at all. Online vendors, such as DIALOG, who sell primarily to organizations rather than individuals, have found it difficult to anticipate which firms will purchase substantial quantities of online information, and which will not.

\section{Organizational Data Gathering Practices and Incentives}

For the most part, information science (IS) researchers have relied on two basic types of organization theories to provide plausible explanations for the data gathering activities of organizational individuals: rational choice theories and closed-system interactionist theories (cf., Boyce and Kraft, 1985; Buckland and Liu, 1995.) Each perspective identifies very different organizational incentives for using information, but both lead us to expect that organizations will gather information extensively. Together, they suggest that three basic logics can explain what drives an organization to gather information: the desire to reduce uncertainty, the need to increase core knowledge, and the desire to reduce anxiety about decisions made under uncertainty. Further, they suggest that particular data gathering practices are associated with each logic. (See Table 1.)

Rational choice theories assume that managers and professionals, such as lawyers, brokers and analysts, will gather and interpret data to reduce uncertainty about the tactical and strategic decisions they must make on behalf of the firm (Cyert and March, 1963; Wilensky, 1967; Larson, 1977; Guy, 1985.) They would expect production managers, for example, to collect internal data about manufacturing process efficiencies when making decisions about proposed process improvements. Data collection need not be exhaus- 
TABLE 1. Data gathering logics and organizational practices.

\begin{tabular}{ll}
\hline \multicolumn{1}{c}{ Data Gathering logics } & Organizational practices \\
\hline Reducing uncertainty & $\begin{array}{l}\text { Rational decision making } \\
\text { Environmental scanning } \\
\text { Basic research }\end{array}$ \\
Increasing core knowledge & Decision legitimization \\
Reducing anxiety & Displaying competency \\
\hline
\end{tabular}

tive, but it should be sufficient to reduce uncertainty among the decision-makers (March and Simon, 1958). This perspective would further expect executives and marketing managers to periodically scan for news reports about events in local and global environments, and to gather industry sales figures and stock prices when assessing the strength of their competitors.

People in organizations also gather data as they perform basic research, or as they build products based on the work of industry and academic scientists (Garvey, 1979; Knorr Cetina, 1981.) Engineers, scientists and managers use this data to understand advances in their industry, and they apply the relevant information they find to organizational activities that increase the core knowledge and competencies of the firm.

While firm members often report that these rationales guide their data gathering activities, organization researchers have found that people do not always use the data they gather for making decisions. Such behavior may appear irrational, but interactionists point out that managers frequently gather information to support a priori decisionsthereby reducing anxiety about "gut-level" decisions, or the decisions that they must make when time pressures prevent advance data gathering, or when data is simply unavailable (Feldman and March, 1981). Even though an executive has already decided to develop a new product line, for example, she may have her staff collect data that supports or legitimates that decision.

\section{From Incentives to Online Use (or Non-Use)}

Rational choice theories explain why every organization should gather and use data, and closed-system interaction theories explain why organization members might gather more data than they use. Therefore, theorists and practitioners alike have expected to see strong trends toward organizational online use, across the board. In practice, however, forecasts based on the application of these well-accepted theories have repeatedly overestimated information use (Dutton et al., 1993; Aumente, 1987; Libmann, 1990.) Many studies of individual information users acknowledge that both print and electronic information resources are used less extensively than information providers and information theorists expect. Lower-than-expected usage rates often indicate problems with media accessibility and human-computer interfaces, but organizational contexts strongly influ- ence online information use (Culnan, 1983; Hesse et. al, 1993; Pfaffenberger, 1990; Grudin, 1993.)

Some computer science and information systems researchers have tried to shift the level of focus of their ICT studies toward individuals working within small groups and organizations to capture selected aspects of organizational context. A wide-ranging set of research studies, loosely categorized as computer-supported cooperative work (CSCW) studies, has examined the situated use of ICTs within complex organizations. CSCW electronic mail studies, for example, have provided insights that explain the differential benefits of organization-level use of ICTs. This work has shown the need for a "critical mass" of users, and has identified the wider social benefits of email use that may accrue to globally distributed organizations (Markus, 1990; Sproull and Kiesler, 1991.) Some CSCW researchers have also examined the incentives for using ICTs like groupware to augment organizational memory (Grudin, 1989; Ackerman, 1994; Orlikowski, 1996.) Their research shows that among different organizations, the same technologies will be used differently depending on the practices and incentives present in each organization.

\section{Environmental Understandings of Online Use}

A few of the studies cited above take external influences on organizational information practices into consideration, but they do not attempt to articulate organizational environments. IS researchers who focus on situational relevance and sense-making, on the other hand, begin to engage the larger context of information use (Dervin, 1999; Wilson, 1973.) Wilson's approach to understanding the non-use of information resources is particularly effective because it contextualizes and makes explicit the institutional influences that are often taken for granted in other research studies (Wilson, 1995.) A few IS studies have adopted this open systems view to gain institutionalist insights into the use of ICTs, and have begun to articulate the organizational environments of information use (Covi and Kling, 1996; Kling and McKim, 2000.) However, robust models of information resource use do not yet include key interfirm coordinations that shape organizational environments (cf. Boyce and Kraft, 1985; Buckland and Liu, 1995, Pettigrew and McKechnie, 2001.) For example, Williams' surveys $(1985,1995)$ show that biotechnology firms have been long term, high volume users of online services, but we do not have a way of characterizing the informational environments of biotech firms. Nevertheless, a brief quote from a librarian at a Silicon Valley biotechnology company provides dramatic evidence of the relationship between online use and characteristics of her firm's environment:

Anytime that we're getting ready to file an FDA submission, we do massive searches in the literature. Those are very time consuming, and usually, we don't get much warning. And they always want the latest data. So it makes sense to wait until the last minute, so that we can search the infor- 


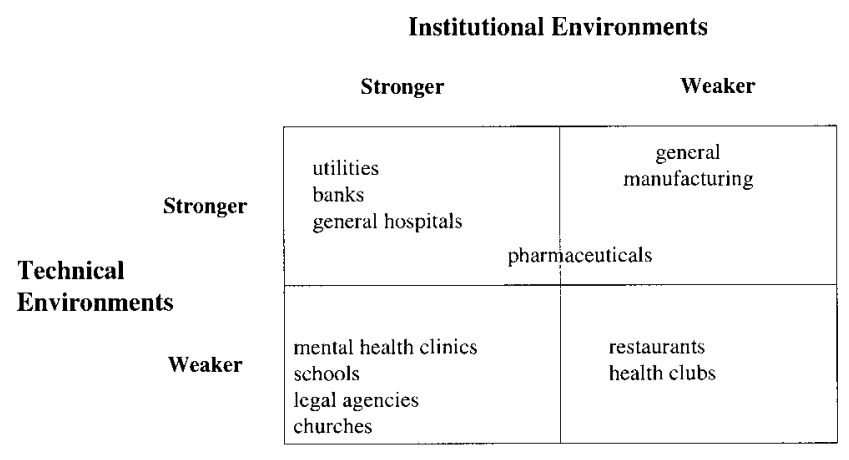

FIG. 1. Technical and institutional environments with illustrative organizations (Scott, 1987:126).

mation [online] and get the most current stuff. Just before submissions, it's crazy for the library, and it's crazy for the regulatory folks as well.

This quote illustrates two increasingly common conditions of organizational life: routine and intensive use of online information, and interaction with regulatory agencies. The biotechnology company in this instance develops drugs and biomedical products. Before it can sell these products in the U.S. it must obtain U.S. Food and Drug Administration (FDA) approval. The most voluminous of many FDA approval requirements is the New Drug Application, which must include information about research done through in-house drug development and clinical trials, as well as references to anything else that has been published about the drug, its compounds, and its medical application. This information shows the FDA what the field knows about the drug application, and builds the case for approval. Data gathering of this nature enables the FDA to fulfill its obligation to ensure that new drugs are effective and safe. To achieve this goal, the biotechnology company, the FDA, and others in the biotechnology industry form relationships with one another within an environment that is defined largely by institutional conditions. Thus, biotech firms' data gathering incentives and informational practices are strongly shaped by the larger industry environment.

To examine environmental influences, organization researchers have increasing adopted open-systems perspectives. "That a system is open means, not simply that it engages in interchanges with the environment, but that this interchange is an essential factor underlying the system's viability" (Buckley, 1967.) With respect to the environment and interchanges of the biotechnology firm mentioned above, Scott's (1987) explanation of the technical and institutional pressures on industry firms provides a helpful open-systems framework. (See Figure 1.) In technical environments, organizations are rewarded for effective and efficient control of their production systems as their products or services are exchanged in a market. In institutional environments, organizations must conform to an elaborate set of rules and requirements if they are to receive support and legitimacy. Institutional requirements may come from reg- ulatory agencies, professional or trade associations, or from general belief systems held by society. All organizations face varying degrees of technical and institutional demands from their environments. In fact, one of the major contributions of this line of research is the concept that all organizations take shape within environments that vary in terms of their technical and institutional environments. ${ }^{2}$

We have found Scott's open systems framework to be extremely helpful in classifying industry environments and in contextualizing information practices in ways that, we believe, can provide better understandings about the sustained use and non-use of online information. As the biotech quote above begins to show (and as we will exemplify further in a later section), there are informational demands associated with both technical and institutional pressures, and these can be amplified or attenuated through interorganizational relationships that are shaped by industry environments.

\section{Environmentally-Aware Study Design}

We know that organizations adopt a number of data gathering practices that include a wide variety of online ICTs, and that some approaches are more effective than others; but fundamental questions relating organizational information use and industry environments persist:

How do data gathering practices and related online ICT uses vary among firms?

Do industry environments constitute informational milieus that influence information infrastructures and practices?

To research these related questions, we designed a study that examines firm members' use of online information services within three different industries, focusing on the ways in which their informational activities support interorganizational relationships.

Online information services. If industry environments influence organizational information infrastructures and practices, one way to characterize that influence would be to examine the differential use of a single ICT type. We chose to study online information services because, as noted above, although prior studies concurred that firms varied

\footnotetext{
${ }^{2}$ Figure 1 depicts the relative strength of technical and institutional pressures on sample industries. This framework was developed to explain differences between hospital environments and industry environments (Alexander and Scott, 1984.) It assumes that institutional and technical (rational) forces are orthogonal, and not necessarily in conflict. The more recent position embraced by Scott and others "is that institutional forces encompass and subsume rational ones. The rules of rationality are set by institutional processes and varyfrom one institution to another." (Scott, 1995:152.) Our findings support this general assessment-the informational influences that characterize these dimensions are interdependent and conflicting. Nevertheless, we find it helpful to retain the orthogonal representation to emphasize that environments can be usefully understood in terms of their institutional and technical dimensions.
} 
widely in their online use, this variation was not well understood.

Different industries. We decided to conduct our study in more than one industry, because surveys have shown that online use varies across industries. A large part of this use variation is unaccounted for, and could be related to important environmental differences that Scott has found among industries. Although widely-accepted information use theories commonly lead to overestimates, open systems theorists would expect organizations to differ in their potential to accrue benefits from extensive use of online services and databases. Firms in certain industries could benefit much more from information-intensive strategies than firms in other industries. While there is little doubt among open systems theorists that environmental factors command attention and can shape an organization's information systems, these effects cannot be understood by examining the environment independently (Scott, 1987.) To study both technical and institutional phenomena, it may be critical to choose the right level of analysis. New institutionalists have found it helpful to extend the boundaries of their studies beyond the organization and into the environment by focusing their research at the industry or 'functional organizational field' level ${ }^{3}$ (DiMaggio and Powell, 1983; Powell and Brantley, 1992; Powell et al, 1996,) and we have adopted that approach in this study.

Interorganizational relationships. At the industry level, interorganizational relationships are seen as key shapers of organizational action. We know from models of coordination that relationships entail informational exchanges (Blau, 1964; Hall et al., 1976; Alexander, 1995), but these have not been systematically characterized. An industry level study can provide descriptions of how informational exchanges become integral to obtaining and sustaining legitimacy; and, perhaps more importantly, how firms can choose among different data gathering practices and online usage patterns, depending on the field environment. Because they extend outside the firm, interorganizational relationships could link environmental concerns, informational exchanges and technical concerns in ways that make differential use of online services and related ICTs more understandable.

Firm members. While industry level analysis is critical to our study, we chose to collect data primarily at the individual level for two reasons. First, some model studies have successfully combined levels of analysis and data collection, and their research has provided poignant insights into the dynamics of information systems in organizations (Markus, 1980; Dutton and Kraemer, 1985; Kling and

\footnotetext{
${ }^{3}$ An organizational field is defined as: "those organizations that, in the aggregate, constitute a recognized area of institutional life: key suppliers, resource and product consumers, regulatory agencies, and other organizations that produce similar services or products." (DiMaggio and Powell, 1983.) Functional organizational fields are industries, broadly construedi.e., organizational systems that are isolated for analysis based on functional rather than geographic criteria. (Scott, 1987:124.)
}

Iacono, 1989.) Second, online services are designed for use by individuals, and most information gathering activities are still performed by people in organizations. Collecting our data at this level could help us avoid the criticisms that other institutional field studies have drawn for not engaging agency. Such data could show where individuals actually can make choices, and how their articulation work sustains interorganizational interactions.

Site selection. Between October, 1995 and March, 1997, we studied the use of online services by 26 California firms in three industries: biotechnology/pharmaceuticals, law, and real estate. The firms were all located within two areas of California (Orange County and the San Francisco Bay Area) that each support an active legal practice, a strong real estate market and a viable biotech/pharmaceutical industry. Using online databases, such as Dun and Bradstreet, to analyze revenue and employee statistics, we ranked the firms within each area and industry. We then correlated this information with online usage data provided by a cooperating online vendor ${ }^{4}$ to identify sample sites that did not use their online services, as well as those that did. Our cross-sectional study included firms that were non-users as well as regular users of online resources, late as well as early adopters, large firms, small firms, and poorly financed as well as richly capitalized organizations.

Industry environments. We had originally intended to select sites from only two industries that each reported high use of online resources: the biotech/pharmaceutical industry and the legal industry. According to Scott's environmental framework, however, this design would restrict our study to two highly institutionalized industries. We had expected the legal services industry to be highly institutionalized. In some respects, The Law can be considered an institution in itself. The biomedical field, although highly technical, is also highly institutionalized and heavily regulated-from physicians and hospitals to drug manufacturers and biotechnology groups. By including the real estate industry-an industry that is somewhat less institutional, also non-technical, and not noted for high use of online services-we ensured that our study organizations would be sampled from a wider variety of industry environments.

Interviews. We gathered data primarily through semistructured, on-site interviews. Our questions to informants focused on their firm's use of online resources and printbased media, as well as their own personal contacts. We discussed the information resources they have and use, and we talked with them about how and why they gather information and when they go online. [See Appendix A for a sample interview schedule.] Often, they would demonstrate their use of a particular online service. During these interviews, people consistently mentioned their firms' interactions with outside organizations when they talked about

\footnotetext{
${ }^{4}$ Our cooperating vendor was Knight-Ridder Information, Inc. (KRI), who at the time of this study was the provider of the DIALOG and DataStar online services.
} 
TABLE 2. Interview sample.

\begin{tabular}{lrrrrr}
\hline & & & & \multicolumn{2}{c}{ San Francisco Bay } \\
& \multicolumn{2}{c}{ Orange County } & & \multicolumn{2}{c}{ Area } \\
\cline { 2 - 3 } \cline { 5 - 6 } \multicolumn{1}{c}{ Industry } & Informants & Sites & & Informants & Sites \\
\hline Biotech/Pharmaceutical & 12 & 6 & & 11 & 5 \\
Law & 9 & 5 & & 6 & 4 \\
Real Estate & 8 & 4 & & 2 & 2 \\
Totals & 29 & 15 & & 19 & 11 \\
\hline
\end{tabular}

using information, and they often linked changes in their data gathering practices with changes in key interorganizational relationships. Thus, while collecting data on information gathering practices at the individual level, we were able to direct attention toward the interfirm associations that influence the use of online services.

In law firms we interviewed librarians, paralegals, associate attorneys, and firm partners. In biotech companies, we included information center directors, information specialists, scientists, marketing managers, and directors of strategic partnering units. At real estate brokerages we included brokers and realtors. We used a nested interviewing approach, relying on inside referrals to collect responses from between one and four informants at each site. Wherever possible, we also observed the use of online resources and services in the day-to-day activities of the people we interviewed. (See Table 2.) A low number of interviews was typical in firms that did not use online resources at all. Also, in a few small firms, the nested interviewing approach did not lead to any other inside referrals because online resources were used by only one person at the firm. While this may seem to be a limitation, in fact it allowed us to better analyze organizational use, because our set of individual informants fully represented online service use within the firm.

Data Analysis. Throughout the study, we used a theoretical data sampling approach to guide our selection of study sites and to refine our inquiry instruments (Strauss and Corbin, 1990.) This method combines concurrent qualitative analysis with ongoing data collection. We followed that analysis with several rounds of coding and thematic analysis at four different levels. Where we had conducted interviews with more than one informant at a firm, we compared and contrasted transcribed interview data at the individual level. Where we had conducted more than one industry firm study in an area, we analyzed interview transcriptions and developed themes at the firm level. We also supplemented our code analysis with data reduction through site summaries (Miles and Huberman, 1994.) We then compared and contrasted the data categories that had emerged within each industry, and refined our thematic analysis by performing a cross-industry comparison of the qualitative categories that characterize these sites, these informants, their activities and their use of online information resources. Both open coding and thematic coding methods were initially used to analyze the interview data. However, we found that, with iterative refinement, thematic coding techniques developed data categories that were more appropriate for industry level analysis.

\section{Results}

Like other researchers of online services, we found as much variation in online use among firms within an industry as between firms in different industries. Interestingly, however, our data show that online usage has as much or more to do with external contingencies as with any internal decisions or preferences of the firm's managers or staff. Within organizational contexts, technical and institutional influences combine to shape data gathering practices and patterns of online information resource use. As we will discuss, some resulting practices, like profiling, have a technical orientation, and some, like documentation, have an institutional orientation. No one orientation pattern or practice set, however, neatly characterizes any industry. Some firms in the study made much greater use of online information than did other firms. For purposes of discussion, we label this pattern of use "intensive". (See Table 3.) A few firms made only "minimalist" use of online services, while the remaining firms can be classified as somewhere in the middle—making "sufficient" use of online information

TABLE 3. Major patterns of online information resource use.

\begin{tabular}{|c|c|c|}
\hline Pattern $^{5}$ & Organizational resource use description & Industry \\
\hline Intensive & $\begin{array}{l}\text { Staffed library or research department, online service contracts and high reported online usage, } \\
\text { local and wide area networks, records management systems, some use of public and industry } \\
\text { information infrastructures. }\end{array}$ & $\begin{array}{l}\text { Biotech/Pharmaceuticals } \\
\text { Law } \\
\text { Commercial Real Estate }\end{array}$ \\
\hline Sufficient & $\begin{array}{l}\text { Unstaffed library, fee-for-service use of online databases, local area network, moderate to heavy } \\
\text { reported use of public and industry information infrastructures. }\end{array}$ & $\begin{array}{l}\text { Biotech/Pharmaceuticals } \\
\text { Law* } \\
\text { Residential Real Estate }\end{array}$ \\
\hline Minimalist & $\begin{array}{l}\text { One online database subscription, heavy reported use of public and industry information } \\
\text { infrastructures. }\end{array}$ & $\begin{array}{l}\text { Law } \\
\text { Residential Real Estate }\end{array}$ \\
\hline
\end{tabular}

* Law firms exhibited 2 more patterns, varying primarily in their mixture of public and private resources. 
TABLE 4. Influences shaping organizational online use.

\begin{tabular}{|c|c|c|}
\hline Influence & Description & Online use effect \\
\hline Regulatory compliance & $\begin{array}{l}\text { Whether an organization interacts directly or indirectly with the } \\
\text { major institutions of its industry, such as the large regulatory } \\
\text { agencies that control activities within the } \\
\text { biotech/pharmaceutical industry, has a strong impact on its data } \\
\text { gathering practices. }\end{array}$ & Increase when interactions are direct \\
\hline Profiling and packaging & $\begin{array}{l}\text { Firm members in all industries collect data to characterize the } \\
\text { expertise and competencies of the people and organizations } \\
\text { with whom their firm forms relationships. These vignettes } \\
\text { describe, or profile, the subject in a specific and limited way. } \\
\text { Similarly, an information package, like a three inch thick report } \\
\text { about a commercial real estate property investment, showcases } \\
\text { the competencies and expertise of the organization putting that } \\
\text { package together. }\end{array}$ & Increase \\
\hline $\begin{array}{l}\text { Customer expectations } \\
\text { management }\end{array}$ & $\begin{array}{l}\text { Clients and customers expect timely, cost-effective information } \\
\text { exchanges. Firms may meet these demands in various ways: by } \\
\text { adding support staff, by developing faster information } \\
\text { processing practices, by purchasing more potentially useful } \\
\text { information resources (both print and electronic media), etc. }\end{array}$ & Generally increase \\
\hline Informational load shifting & $\begin{array}{l}\text { Firms can separate information use incentives from data gathering } \\
\text { activities. Even when a firm is strongly incented to gather and } \\
\text { use information, its interorganizational relationships can } \\
\text { provide opportunities for shifting the responsibilities of data } \\
\text { gathering across organizational boundaries. }\end{array}$ & Decrease \\
\hline Information infrastructural richness & $\begin{array}{l}\text { In some industries, curation, publication and distribution of } \\
\text { industry-relevant information resources are performed by a } \\
\text { separate entity that is publicly funded or industry-member } \\
\text { supported. }\end{array}$ & $\begin{array}{l}\text { Increase when infrastructure is } \\
\text { online, decrease when not online }\end{array}$ \\
\hline
\end{tabular}

in relation to the informational influences of their environment. $^{5}$

By following the data analysis process described in the previous section, we identified five influences that derive largely from the interorganizational relationships of the firm (see Table 4.) Those influences make up a set of data gathering incentives and industry practices that shape the use of online information by the organizations of this study:

(1) Interaction with regulatory agencies, as illustrated by biotechnology firms who submit documentation about

${ }^{5}$ Firms adopt these patterns based on overarching technical and institutional pressures in the industry environment, as well as available industry information infrastructures and the firm's own interorganizational relationships. Biotech firms exhibit only intensive or sufficient patterns. Those that interact directly with regulators are generally intensive information resource users, while firms that interact indirectly with regulators or that have less regulated products, such as some medical devices, adopt the sufficient type of infrastructure. Commercial real estate brokerages adopt the intensive pattern; residential brokerage patterns are either sufficient or minimalist. The two residential brokerages in this study that serve technologysavvy Silicon Valley workers and upscale Orange County home buyers have sufficient information resource configurations. The one minimalist residential brokerage we visited serves only retirement-community homebuyers. Law firms show the widest range of information resource use, adopting all three patterns as well as some gradations in between the patterns that we have classified. Law firms on the intensive end of the scale generally serve large corporate clients; the one minimalist firm serves individuals, and relies heavily on public law libraries and university services to meet informational demands. What appears to allow for this greater range among law firms is the availability of a publicly supported information infrastructure. product and product effects to regulatory agencies for review and approval, and by law firms whose clients are regulated by such agencies.

(2) Demonstration of competence and superior service to clients, as illustrated by the packaging of information from online and other information sources in the real estate industry, and by the profiling of clients, experts, competitors and markets in all three industries.

(3) Client expectations for timely, cost-effective information exchanges, such as corporate clients' demands for immediate, specialized legal advice outside normal business hours.

(4) Opportunities to obtain information from associated industry organizations through load-shifting, as outsourcing, partnering or purchasing information services.

(5) Existence of industry-wide infrastructures to provide critical information, such as law libraries and real estate multiple listings services.

The first two influences lead to increased use of online information resources. Firms that interact directly with regulators, and those that seek to demonstrate their own competencies or to evaluate other firms' competencies, use more online information than firms that do not interact with other organizations in these ways. The third influence may lead to either increased or decreased online use, depending on the types of resources (including support staff) that are available to busy firm members in the evenings or on weekends; but time pressures generally lead to increased use of online information resources. The fourth influence leads to decreased use. When firms have an opportunity to shift data gathering responsibilities to another firm, they will do less 
data gathering themselves. The fifth influence may also lead to decreased use if the infrastructure provides an alternative to going online, such as publicly supported law libraries. But it will lead to increased use if the infrastructure is online, such as the multiple listing services of the real estate industry. Although one industry may appear to have more information gathering pressures than another, firms within that industry respond differently to these pressures. Some detailed examples will serve to illustrate these findings.

\section{Regulatory Compliance}

External regulation explains some important differences in information resource use. Firms that work closely with regulatory institutions on a regular basis gather more data and use information resources more intensively than firms that do not. Many biotech companies, for example, interact with large regulatory agencies, such as the U.S. Food and Drug Administration (FDA), the Environmental Protection Agency (EPA) and the Patent and Trademark Office (PTO). These firms reported collecting more data than companies that do not interact directly with regulators. ${ }^{6}$ Several informants pointed out that meeting FDA requirements is a major incentive for gathering data. As noted earlier, the FDA legitimates drug discovery and production by approving products as safe and effective. FDA approval is required to sell ethical drugs or other bioactive products in the U.S. Biotech firm members regularly gather scientific publications through print and online resources, and coordinate those with internal, proprietary documents when assembling the voluminous information packages that the FDA requires. A biotech firm that conducts its own clinical trials and submits new drug applications to the FDA may be required to ship truckloads of documentation to Washington, D.C., and to manage the associated data records for a period of ten years or more before the FDA approves the drug for sale in the U.S., as this scientist confirms.

Every single protocol is filed with the FDA. . .At the end [of the clinical trial phases] you'd file what's called an NDA, which is a New Drug Application. That NDA contains everything that you've ever done on that particular drug. So it can be 300 volumes of stuff. It goes by truck sometimes to Washington.

The PTO, which gives biotech companies a legal sanction for exclusive use of a scientific innovation or a trade name, is another key regulator. Patent searches and patent filings are commonplace activities in biotech research. The FDA, the PTO and other regulatory agencies routinely require companies to submit detailed information packages to state and federal inspectors. This is one way that such agencies exercise their oversight responsibilities. Another

\footnotetext{
${ }^{6}$ Informant-reported usage estimates and KRI revenue statistics support this observation about interacting with regulators and data gathering volume.
}

way is through onsite inspections. Interestingly, one agency investigator indicated that information package submittals are being requested more often in lieu of onsite inspections, especially in California, where the biotech industry is growing rapidly and agency budgets have constrained the number of inspectors in the field.

\section{Profiling and Packaging}

Interorganizational relationship management influences explain some other key differences in firm use of information resources. The resulting practices take two general forms. One is profiling - a method of characterizing an organization or an individual by gathering data about past achievements, recent activities, economic strengths, technical weaknesses, industry affiliations, market share, etc. This pastiche of information tells a story about a firm or its members, and helps the person who constructs the profile to make some judgments about them. ${ }^{7}$ The second is information packaging. Client interaction requirements strongly influence data gathering and packaging practices-particularly the technologies that are part of the package. A firm's desire to demonstrate competence to current and potential clients can significantly increase its use of online information resources.

Organizations may gather information to monitor the activities of competitors and markets, to select among potential organizational partners, to choose which experts the firm will hire or which clients the firm should pursue. Such decisions require information from trusted associates, past experience, and the profiles constructed using online and print resources. ${ }^{8}$ Biotech firms construct profiles when they contract experts or physicians for clinical trials. They also monitor competing biotech companies by gathering patent data. And they gauge their own company's strength in new markets by comparing their technologies to those of competitors, as reported in the business literature and in market research reports. For some firms, such as the one that employs this researcher, profiling is a fundamental data gathering activity.

Before we start doing business with any company, we always research the company. We will search financially about the company, business strengths, their marketing plans. We'll look at all of the press releases that they've made. We'll look at key players in the company_-get bio's on those, histories, where they came from, where they studied, who they've done business with in the past. De-

\footnotetext{
${ }^{7}$ Profiling is sometimes referred to as competitive intelligence gathering or corporate intelligence, and researchers who work in this area have their own professional association, the Society of Competitive Intelligence Professionals.

${ }^{8}$ Profiling, as observed in this study, differs from documenting. Documentation involves the detailed recording of activities, such as the steps followed in a clinical trial phase. Documentation is used for legitimization of activities, whereas profiling is used to characterize expertise and to make predictions about future behaviors.
} 
pending on the type of relationship that we want to develop with this company, we will know as much about them as we do about ourselves.

Law firms, too, construct detailed personal profiles, particularly when they consider hiring an expert witness. Law firm informants report that, as the legal industry has become more competitive, they have begun to profile judges, potential clients, and even existing clients. In the past, they might have relied exclusively on referrals for new clients and traditional loyalties to maintain existing clients. Attorneys also monitor their clients' competitors by comparing a client's patented technologies and its scientists' profiles with those of other companies in the client's industry. Whether biotech company members, for example, perform these data gathering activities or whether the company's law firm does this work, depends on the client-firm relationship.

In the real estate industry, profiles are part of the core product that brokers offer to their clients. Real estate informants report that they profile everything and everyoneproperties, clients, brokers, and markets-even their own firms. This researcher describes how her corporate office profiles its branch offices.

\begin{abstract}
At our corporate office, they know every single deal that's been done by every office in the country. They're constantly combing through that data to see what can they find, and to learn about who is our target. [You need to] know what markets you really excel in and know what markets you're wasting your time and your effort and your money in going after.
\end{abstract}

The corporate office uses this comparative data to measure the performance of its branch offices, and it also offers these compilations to its clients in the form of real estate market analyses.

\section{Customer Expectations Management}

Relationship management also affects information use when online technologies are employed to help meet customer expectations for performance. For example, a law firm's incentives to use new information technologies may come not only from the volume of documentation that it must manage, but also from the increased speed at which attorneys try to work, and from the clients with whom they need to communicate. Attorneys report that their clients expect increasingly rapid or even immediate answers to questions. This law firm information center director explains why many firms can feel pressured to go online.

The deals are happening faster. Life is happening faster. It's just been speeded up. So [the clients] want results. They want [attorneys] to know, right away. They want people to specialize, and know areas, and give them an answer quicker. . [The attorneys] are called day in and day out, on their car phones. . . It's a very demanding job to be a lawyer, and to support them is very difficult, because you're trying to gear up to that speed. Not only in the information area, but also in their files. They've got to have that file now! That guy is calling!. . . We have to improve technology because of the demands of the clients.

Several law firm members mentioned their need to economize operations, while simultaneously increasing service, to retain clients. Firms that provide full-service to corporate clients have tried to find information management synergies across firm departments to achieve more efficient use of their records management systems and online resources. Some firms, however, continue to gather data from public or locally shared resources and to prosper in the company of larger, more technologically sophisticated firms-perhaps, in part, because their clients are generally less-demanding individuals and small companies.

In the real estate industry, both brokers and realtors use information packages and information technologies to signal organizational competence to buyers, sellers and underwriters. Moreover, real estate informants indicate that, as a result of their increased interaction with institutional clients, the property information package and its presentation are becoming increasingly sophisticated.

Presentation does count. And the fact is that more and more of the competition has this [information presentation] technology at their disposal. So, if you come into a client presentation and you're still using the same old DOS-based dog and pony show, you run the risk of looking like you're technologically not as adept as your competition.

For some commercial properties, a three-inch thick report that includes detailed economic projections is frequently delivered as part of a professional, multi-media presentation promoting the proposed investment. These packaged presentations are a vital part of the relationship building process, particularly for commercial brokers and their institutional clients. The information package legitimates investment decisions with supporting data, thereby reducing anxiety about the property sale or purchase, and meeting underwriter demands for quantitative investment data. The information technologies brokers use to present that data also instill confidence about themselves and their firm.

\section{Informational Load Shifting}

We have illustrated the ways in which biotech firms are incented through regulatory mandates to go online and to construct voluminous information packages. Firms vary, however, in how closely they work with regulatory agencies. Biotech companies that interact only indirectly with regulators reported gathering less data and using fewer information resources than firms that interact directly. Some companies routinely sell their discoveries to large pharmaceutical firms that have the resources to manage costly clinical trials and FDA approval processes, rather than try- 
ing to manage these themselves, as one research director explained.

In developing drugs, you always have to go into the clinic to test them. So clinical trials are very expensive. That's where we would hand off to somebody else.

Other firms may opt to develop the drug in-house, but may try to avoid some direct interaction with regulators by forming reciprocal relationships with peer firms that do interact directly. They may, for example, partner with another firm to use its already-FDA-approved facilities, thus avoiding some portion of the documentation-intensive compliance activities. Firms may also hire an attorney to mediate their regulatory interactions. To better service their biotech clients, a few law firms reported that they have developed new legal practice areas. When they do this, the data gathering practices of the law firm may change in ways this law librarian describes.

We have a very healthy biotech segment of our clientele. The kind of work that we have to do in the [firm's] library takes us over to the medical school library a lot more than it used to. Biomedical devices are a very large part of our practice, and we have an FDA practice now.

Several law firm informants reported that a large portion of their work involves gathering documentation to submit filings on behalf of their clients to regulatory agencies. Such clients have effectively shifted the load of data gathering responsibilities to their attorneys who then interact directly with regulators, on the client's behalf. Thus interacting with regulators can influence how law firms gather data and use information resources. Of course, the legal industry is also highly focused on interacting with other institutions, such as courts and legislative bodies, which place additional data gathering and information packaging demands on the firm.

Unlike biotech companies, real estate brokerages are not heavily regulated. And unlike law firms, they do not generally interact directly with institutions or regulators on behalf of their clients. Most of their contacts with financial institutions, for example, are handled through escrow agents or mortgage brokers. However, commercial real estate brokers do interact with institutions as clients, and that relationship can strongly influence data gathering practices. As this broker explains, institutional clients routinely demand more data to support real estate investments than noninstitutional investors require.

[Institutional clients] need to have demographics. They need to have lots of [comparative data.] They need to have projected earnings. A lot more homework is done, and rightfully so, especially if it's a pension fund or a life insurance company, or a publicly traded REIT, in that those types of owners are using other people's money. Either as a public shareholder, or if you own life insurance and you pay your monthly fee to the life insurance company, that's your money. If you're in a pension fund, obviously that's your money. It's the little man's money that they're investing. So they have to be very, very careful.

Investment regulations and good investment practices dictate the kinds of information that an institutional investor must gather about a real estate property, but not who must do the data gathering or who must compile the information package. Clearly, where large commissions are involved, real estate brokers may be incented to carry some or all of that load.

\section{Information Infrastructural Richness}

One more influence helps to explain differences in online information resource use-the existence of an industrywide information infrastructure supported through commercial or industry efforts. Institutional environments often include basic infrastructural components that are used collectively by industry organizations (Tolbert, 1995.) The legal industry is a highly institutionalized environment, and it supports an information infrastructure of law libraries and legislative archives staffed by people who facilitate the dissemination of legal information. One Appeals Court librarian typically takes advantage of this infrastructure when he needs to obtain legislative documents, as described in the following example.

What would happen is I would have called Senator Davis, who is no longer Senator. I would have called his office and talked to some underling and said "Do you have any committee reports or anything dealing with Senate Bill 839?" And they would have then checked their files and said "Oh, yeah. We've got this. We'll send it out to you." ... They're only there to provide information and do whatever they do.

He can choose from a number of different data gathering options when procuring public documents. And he frequently, though not always, chooses the no-frills, economical distributions made by legislative staff members. He also noted that he frequently has yet another option-downloading public documents from the web - as staff members add more and more documents to California legislative web pages. Law firms and court units, like this one, can choose not to use commercial online services nor to purchase books and other commercial publications, because they have an industry infrastructure that supports affordable alternative forms of information access. In the U.S., law libraries are publicly established and maintained. Many law firms, however, maintain their own libraries for convenient access to frequently used resources. Occasionally, just having a law firm library provides some privileged data gathering opportunities. Law firm informants indicated that libraries of all kinds readily share information resources with law libraries that they would be reluctant to loan to other organizations or individuals.

One intellectual property law firm, LeanLaw, relies very heavily on this legal information infrastructure and its local 
extensions-using these almost exclusively, as this legal assistant describes.

[At LeanLaw] everything's done from books. [The attorneys will] go upstairs to the law library there. . Its just part of the arrangement we have with [another law firm in the building]... They do allow us to use their LEXIS and NEXIS. So we can go there in their library, and they'll get you set up. . .Or [the attorneys will] go to the law library in Santa Ana and do their research that way.

LeanLaw does not maintain a library, and subscribes to only one online trademark database. The firm can choose not to purchase most of its own information resources because it can obtain them by forming quid-pro-quo relationships with other law firms, and by using law libraries and other public resources, like university libraries. LeanLaw informants admit, however, that gathering data in this way can take time.

Companies in other industries may not have the support of a publicly subsidized information infrastructure. In many industries, the type of cooperative, sharing activity that is common among law firms may be considered imprudent or even illegal. But organizations in some industries have found ways to pool and protect valuable industry information. Third party information services have established a fundamental information infrastructure in the U.S. real estate industry, for both commercial and residential brokers. In exchange for exclusive publishing rights, multiple listings services provide restricted distribution of information on properties offered for sale by brokers within a bounded geographic region. These publications may be offered online, in print format, or both, but they are distributed only to local real estate industry professionals. By gentlemen's agreement, this information is not offered to the general public. These seemingly fragile arrangements have sustained a critical information resource for real estate brokers for over thirty years. All of the brokers and realtors we spoke with used one or more of the online multiple listings services on a weekly, daily or sometimes hourly basis. Some hinted, however, that arrangements with local multiple listings services were breaking down under pressure from national multiple listings services that offer better information access to a wider geographic range of property offerings. Others noted that web-based property listings could change the dynamics of the residential real estate industry by making information about property offerings available to the general public.

\section{Discussion}

When taken altogether, these varied instances of online service use paint a rich picture of informational practices and motivations among biotech, law and real estate firms. Technical considerations clearly drive online data gathering for basic research, for sizing up the competition, and for evaluating firm performance. Institutional considerations of regulatory demands and industry information infrastructures

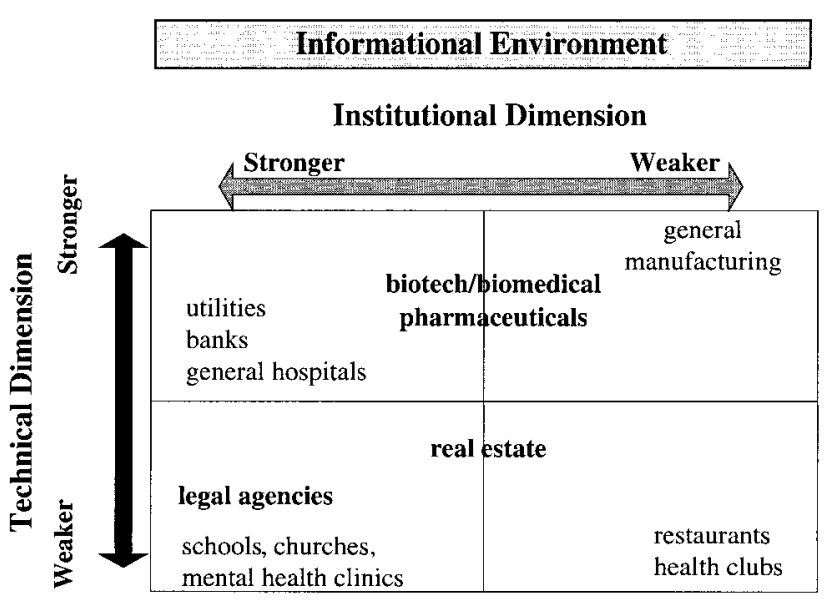

FIG. 2. Informational environment with technical and institutional dimensions (adapted Scott, 1987:126).

also drive online use very strongly, in ways that may either amplify or attenuate these informational practices.

\section{Interdependent Technical and Institutional Influences}

By placing the industries of our study into Scott's model, we can better visualize how our set of influences interact to shape patterns of online use (see Figure 2.) Strong institutional influences reflect the need to comply with regulatory demands by producing documentation for examiners and auditors. Strong technical influences reflect a firm's incentives to manage customer relations by profiling competitors, markets, clients and experts. This placement, supported by analysis of our study data, suggests that an informational dimension can be articulated to further describe industry environments. In our depiction, this informational dimension is aligned with Scott's orthogonal representation of technical and institutional environments.

In the biotech industry, where both technical and institutional influences are strong, incentives for gathering data and using information resources are high. Sophisticated processes in scientific drug discovery, highly competitive market economics, and the practical difficulties of production exemplify a biotech firm's technical demands. Regulatory compliance, and affiliations with hospitals, universities and world health organizations exemplify a biotech company's institutional demands. In law firms, institutional influences are relatively strong, but technical demands are generally weaker than for biotech firms, although increasing competition in the legal industry has strengthened technical influences on law firms. Profiling and documentation are pervasive practices among law firms, but these practices develop differently in response to incentives for information resource use across widely divergent industries. In the real estate industry, where both technical and institutional demands are lower, brokers actively profile properties and markets, but produce relatively little documentation unless the brokerage serves institutional clients. 
Figure 3a

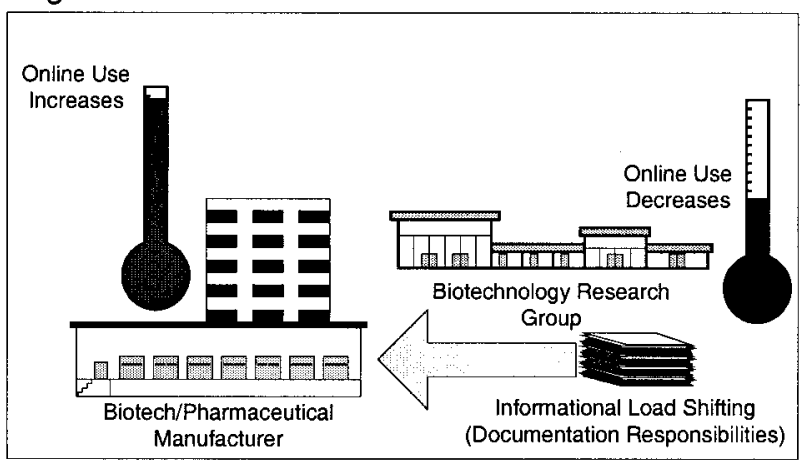

Figure $3 c$

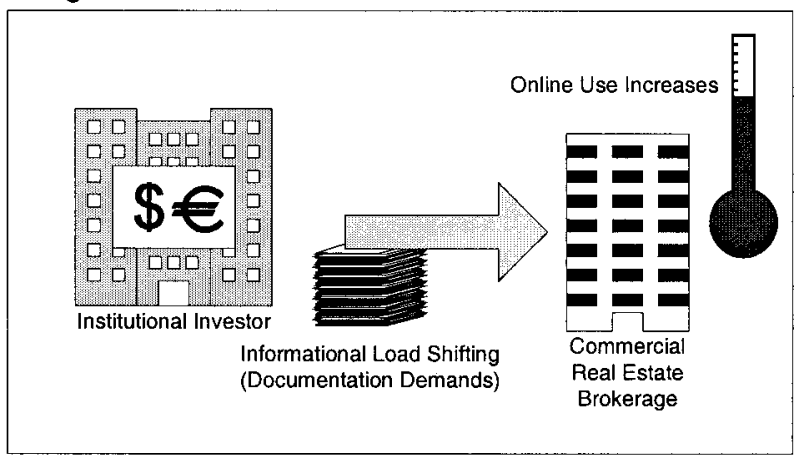

Figure $3 b$

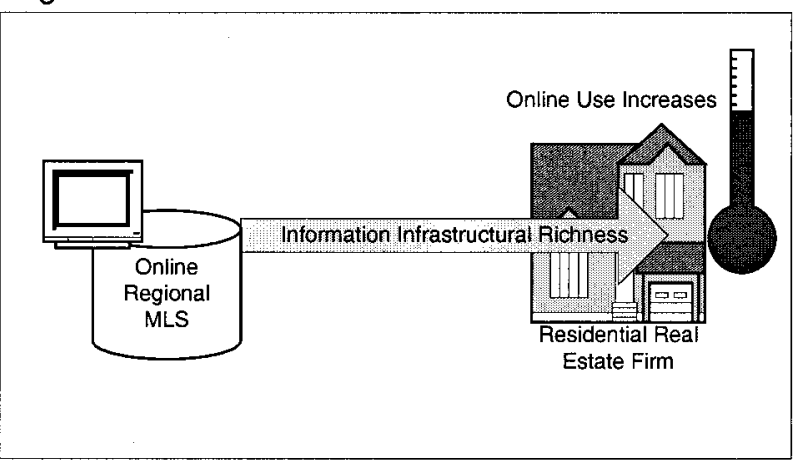

Figure 3d

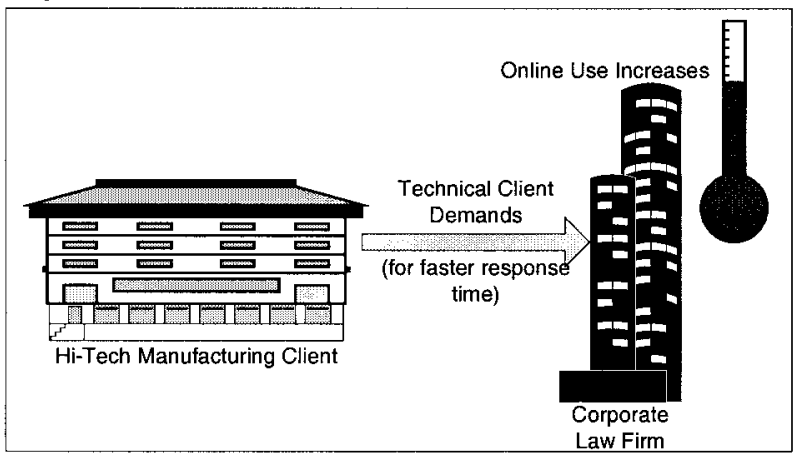

FIG. 3. Interorganizational relationship influences in informational environments.

\section{Informational Environments}

An informational dimension can be helpful in describing the underlying pressures that shape industry environments. As we have seen, however, firms respond differently to those environmental influences, based on their interorganizational relationships. Opportunities to partner with other firms or outsource key activities can reduce both institutional pressures and technical pressures in biotech firms. This informational load shifting may either increase or reduce industry-level pressures on a firm to gather and use online resources, depending on whether the load is shifted into or out of the firm. (See Figure 3a.) Industry informational infrastructures in law and real estate, on the other hand, support intensive informational practices, whether print-based or online. Industry information infrastructures may encourage online use, if the infrastructure itself is online, or discourage online use, if it is print-based. (See Figure $3 \mathrm{~b}$.) Institutional clients bring institutional pressures into the real estate industry by pushing commercial brokers to perform more documentation and legitimization activities. (See Figure 3c.) Strongly technical clients, like hightech manufacturing companies, bring technical pressures into the legal industry when they demand that their law firms pay more attention to time constraints and bill at more competitive rates. (See Figure 3d.) By adding these dynamic elements to our depiction of industry environments, we can begin to model the informational environments of various industries.
This conceptualization does not make the data gathering and information use practices of any particular firm predictable, but it can help researchers, firm managers and ICT providers evaluate which information use patterns are most viable for a firm by drawing attention to its industry environment, its clientele, and its opportunities to form interorganizational relationships that shift data gathering responsibilities across organizational boundaries. It can explain much of the variation in online use that we found within and across the industries of our study (refer to Table 3.) For example, even though an industry like biotech/pharmaceuticals is highly regulated, not all firms in that industry adopt the intensive data gathering practices needed to interact directly with regulators. Many biotech firms distance themselves from regulators by outsourcing, partnering or coordinating their activities with other firms. In the process, they shift data gathering incentives, information packaging responsibilities and the consequent use of online information resources across organizational boundaries. They also work with regulators through their law firms, diffusing the institutional pressures of regulatory policy into the wider organizational community. That kind of diffusion can account for some of the intensive information use that we find in less heavily regulated industries, like real estate. Commercial realtors compile detailed investment packages in response to a complex set of incentives that coordinate the practices of financial creditors and their borrowers in ways that seek to minimize institutional risk. 
These interfirm coordinations shift data gathering incentives and activities across organizational and industry boundaries. Other influences build upon one another to create a rich informational environment that shapes online use. In an industry where firms interact with regulators and shift data gathering responsibilities in various ways, industry information infrastructures can provide additional options and incentives for using (and not using) online information resources. Subsidized access to print materials, such as that provided through staffed law libraries, may make more expensive online services seem unattractive. Free web-based distribution of legislative materials can encourage online use without creating any incentives to use feebased services. Conversely, the exclusive provision of critical industry information through fee-based, member-supported online resources, like multiple listings services, can create huge incentives for going online.

\section{Constrained Choices in Informational Environments}

In our characterizations of informational environments, we have focused on the choices that organizations make about using information and information resources. Our examples show that information does not flow freely within and among organizations; it is pushed, pulled, created, packaged and presented by people in one organization to members of other organizations. People respond to technical and institutional pressures in their local environments, make constrained choices about gathering data and using information resources, and coordinate with individuals in their own firm and other firms to accomplish their assigned tasks. The discretionary choices that fall to individual firm members, and the articulation activities that they perform, make organization-level choices work.

Within the informational environments we observed, individual actors can and do make choices about using information resources including when to go online. But their choices are constrained by decisions made at the organizational level about which clients the firm will serve, how it will interact with regulators, how the firm will use existing infrastructures, and the ways that it will manage production data in-house. These decisions, largely influenced by external contingencies and interorganizational relationships, affect organizational data gathering practices and the use of online services, as well as other types of information resources. In other words, the informational dimension of institutional and technical environments circumscribes the domain in which rational choices about online resource use can be made by individuals.

Some individuals have many choices, like the Appeals Court librarian in an earlier example who could obtain legislative reports in print, by fax, via outside services, or sometimes from the Internet. Others have fewer choices, like the real estate broker who can only get property information from one regional multiple listings service in print or online. Choices about going online are often discretionary because of the redundancy of information media. People in our study reported using a number of different information resources to compile profiles, to gather data about partners or subcontractors, to assemble convincing information packages, and to share public or industry-wide data. Time and cost constraints also restrict choices. In the legal industry, we heard that just gathering the required information is not enough. Information must also be quickly communicated to the client. In biotech, firms use online resources to get last minute updates of information needed for regulatory compliance submissions. In real estate, the property information package and its presentation must display a high level of information resource sophistication. Low-tech media do not convey that "information resource competency" message as effectively as online technologies and multimedia presentations. People frequently emphasized that the key motivations for using online information resources are to avoid the time delays associated with using other information resources, and to display technological competency to clients and potential clients.

When informational environments seem too constrained, people can and do introduce new processes, lobby upper management for the adoption of new technologies, and begin to take advantage of the opportunities that new technologies can present for developing more viable data gathering practices. ${ }^{9}$ But most often, they select practices and technologies from an organizationally chosen set to come up with something that works for the firm.

\section{After the Web ...}

Although our study is not longitudinal, continued analysis of our findings in light of related research leads us to believe that the influences we described have been shaping informational environments since the early 1980's, and that they will do so for some time to come-even after the Web.

\section{Environments, Ecologies and Institutions}

Other researchers have made similar observations about the relatedness of ICTs and environments. Nardi and O'Day (1999), for example, have provided detailed contextualizations of ICT use, which they characterize as information ecologies: "In our research studies, we have seen examples of responsible, informed, engaged interactions among people and advanced information technologies. We think of the settings where we have seen these interactions as flourishing information ecologies. Each of these ecologies is different from the others in important ways. Each has something unique to teach us, just as we learn different things about biology from a coral atoll, a high desert, a coniferous forest. We suggest that these examples be read as stories that

\footnotetext{
${ }^{9}$ See Lamb and Kling (in press) "Social interaction through information and communication technology: reconceptualizing users" for a detailed discussion about how firm members in this study make these choices, shape ICT use within the firm, and proliferate data gathering practices across industries.
} 
TABLE 5. Intranet study survey preliminary results.

\begin{tabular}{lccc}
\hline \multicolumn{1}{c}{ Industry } & Sample year & $\begin{array}{c}\text { Sample size } \\
\text { (includes non- } \\
\text { respondents) }\end{array}$ & $\begin{array}{c}\text { Intranets not } \\
\text { Intranets } \\
\text { considered or not } \\
\text { planned }\end{array}$ \\
\hline Health care & $1999-2001$ & 65 & 43 \\
Manufacturing & $1998-1999$ & 67 & 29 \\
Law & $1998-1999$ & 61 & 31 \\
Real estate & 2001 & 81 & 30 \\
Restaurants & 2001 & 59 & 10 \\
Totals & & $333^{*}$ & 19 \\
\hline
\end{tabular}

$* 78 \%$ Response rate.

model a holistic, ecological approach to technological change." This approach views each organizational instance of situated use as a unique set of interactions that has grown over time to make use of information and ICTs in specialized ways.

While Nardi and O'Day emphasize the differences-the unique and fragile nature of each ecology_our analysis highlights important similarities among organizational informational environments, as well as interdependencies and trajectories of influence that cross organization and industry boundaries. In particular, our framework explains how institutional logics, when combined with technical demands, can affect firms in a variety of industries. In all three industries of our study, for example, online technologies and infrastructures formed integral parts of the informational exchanges that create and sustain legitimizing interorganizational relationships-often through the iterative construction of voluminous, carefully packaged and impressively presented documentation.

Bowker and Starr (2001) have extensively examined the simultaneous constructedness of institutions and their information systems, and our study further emphasizes the value of examining the constructivist aspects of ICT use-not only to better understand ICTs, but also to better understand organizations. DiMaggio (1988) has also identified the constructivist approach to neo-institutionalism as one of the most promising ways forward for organization theory.

\section{Using Intranets in Informational Environments}

In our ongoing research, we have sought to incorporate social constructivist perspectives into our view of informational environments (Giddens, 1984; Berger and Luckman, 1967; Bijker et al, 1987; Bijker,1995; Orlikowski and Gash, 1994; Mack, 1990.) If, as we suspect, informational environments shape not only online service use, but also the use of other ICTs - particularly Internet ICTs-constructivist theories will provide critical explanations of those shaping processes.

To overcome some of the limitations of the online study we have described in this paper, and to further test our informational environments concept, one of the authors is currently conducting a study of intranet use in midwest U.S. firms. This study will examine whether the influences for online information use with one kind of organizational ICT (online information services) can be carried over to understand the use of another organizational ICT (intranets.) ${ }^{10}$ The study is being carried out in three phases:

1) Industry surveys to determine which firms have intranets, for how long, and for what general use; followed by site visits to a few firms;

2) In-depth case studies in each industry to further examine the context of use and the contents of the intranets; and to determine what influences intranet development and use; and

3) Visits to organizations and institutions that seem to influence intranets in the case study sites to verify that influence and to understand how those firms or individuals use intranets themselves.

The industries under study span the range of industry environments dimensioned by Scott (1987): hospitals, manufacturing companies, law firms, real estate firms and restaurants. Based on the analysis presented above, we expected to find that most hospitals would show intensive use of intranets, most restaurants would show minimalist use of intranets, and that firms in the other industries would fall somewhere in between-varying largely because of their interorganizational relationships.

Briefly, we want to present one very preliminary set of results from the intranet study to help readers gauge the value of thinking about ICT use in terms of informational environments. The intranet study industry surveys have been completed. (See Table 5). As expected, organizational intranet adoption and use follows a pattern that is in keeping with our informational environments view. (High, relatively fast adoption and use rates among hospitals; low, relatively slow rates among restaurants-with the rest in the middle.) This is an important finding, because other surveys and projections that do not make an environmental differentiation among industries, project inaccurate, overly optimistic intranet adoption and use estimates (Pincince et al., 1996;

\footnotetext{
${ }^{10}$ See Lamb (1999) for a detailed discussion of the intranet study methodology.
} 
Sage Research, Inc., 1997; Upton, 2001.) One survey projected that the U.S. had reached intranet "saturation" in 1998 (well before most of the firms in this survey had considered an intranet.) That study stated that by the end of 1999, two thirds of all firms having more than 10 employees had implemented intranets (Upton, 2001.) In our own survey, five firms with fewer than 20 employees had intranets ( $21 \%$ of respondents in that category), 16 firms with $20-50$ employees had intranets $(33 \%$ of respondents in that category). While IS researchers might discount the Upton (2001) survey for faulty sampling methods, their industry counterparts may be less discerning, and so more easily misled by such publications.

In terms of patterns of use (cf., Table 3), we also see some encouraging early results from the intranet study. There is some correlation to the minimalist, sufficient, and intensive classifications that appear strongly tied to some of the same influences we identified earlier. For example, regulatory compliance is often the reason for intensive intranet use (Lamb, 2001.) Also, influential client demands and interorganizational interactions are pushing the boundaries of intranet systems integration (Lamb, 2002.) We are beginning to see some instances of load shifting related to intranets (i.e., some merging firms can give up existing intranets and off-load those informational practices, but others cannot.) And, profiling practices have made the transition to intranets in a big way: the phone directory (with extended descriptions of employees, departments and project teams) is the killer app of the intranet (Chee, 2000.) This new study is ongoing, but already we can point to the value of an informational environments approach in understanding the use of intranets, and potentially other ICTs. In the aggregate, this approach can project better estimates of ICT implementation and use. In the specific, it can help firm managers tailor ICT adoption and use plans to better respond to prevailing industry influences and to anticipate the informational demands of interorganizational relationships.

APPENDIX A. Online services study interview instrument.

\begin{tabular}{|c|c|c|}
\hline \multicolumn{3}{|c|}{ IRIS: Interorganizational Relationships and Information Services } \\
\hline Semi-Structured interview with & $<$ name $(\mathrm{s})>$ & $<$ title(s) $>$ \\
\hline$<$ company name $>$ & $<$ address $>$ & $<$ date $>$ \\
\hline$<$ phone number $>$ & & $<$ time $>$ \\
\hline$<$ name(s) of interviewer(s) $>$ & Systematic Study Design & $\begin{array}{l}\text { File: }<\text { interview } \\
\text { guide }>\end{array}$ \\
\hline
\end{tabular}

1. Basic Questions

Who am I interviewing?

What's the major focus/product of this firm? What is the general technological orientation of this firm?

Who are their competitors?

2. InterOrganizational Relationships (IRs)

Clinical Trials, Expert Witnesses,

Subcontracting, Investments

Persistence over time

Frequency

Importance

Which ones involve OI resource use at this firm?

\author{
What "department" are they in? \\ What do they do there? \\ What is the relationship (of this person) to the rest of the firm? \\ What is this person's educational/experiential background? \\ What are their professional affiliations? \\ What is its relationship to the rest of the industry? \\ Does everyone have/use a computer? \\ Does everyone have/use email? \\ Does the firm have an "attitude" about computer/online use? \\ Technophilic/technophobic? \\ What is the competitive environment like? \\ Are there times when competition is intense? \\ Are there alliances or cooperative associations? \\ What about mergers, subcontracting, partnering, outsourcing? \\ How do regulators interact with the firms?
}

Mention we have seen OI resources used during these:

Used in forming these relationships?

Used to check out clients/customers?

Used to check out competitors/opponents?

Used during these relationships?

Ask about any other IRs

What is the context of these IRs?

How many of these over the years?

Are these new kinds of IRs for this firm?

How often (in a year) do these IRs occur?

Do these IRs bring in a lot of revenue to the firm?

Do these IRs bring prestige to the firm?

What fraction of OI use is for IR or outside firm research?

What fraction of OI use is not linked to IR at all? 
3. Activity Sequences of IRs

What is done?

In what order?

Where do information resources fit in?

How is the IR established?

How is the IR maintained?

Were things always done this way?

Are any new ways of doing these being tried?

4. Intermediary Roles (re: Activity Sequences)

Who does what?

What is their relationship to other intermediaries inside the firm?

How do they share IR information?

Is intermediation a driver of certain types of activities?

5. Conceptualizations of roles of resources Accuracy or completeness of identify picture that can be constructed from all resources

Who constructs the identities?

Who interprets the constructions?

6. OI Usage and Changes Over Time

Overall

In Context

How much do they use? (yearly/monthly)

How critical are OI resources?
Electronic media?

Print-based media?

Personal contacts?
Who gets what type of information?

Outside the firm?

Is there a shift from personal contacts to databases?

Make this concrete: How many now vs. before?

Is there a shift from org. contacts to other intermediary contacts? (e.g., more lawyers and consultants doing research?)

Make this concrete: How many now vs. before?

Professional affiliations?

What kind of activity does it drive?

Is OI researching that kind of activity?

What's perceived to be best?

Why?

Are some resources more legitimate than others?

Gathers the information

Compiles the reports

Is there an increase/decrease/shift in kind?

Per unit (economies of scale) or across the board?

When is it used most?

Are these instances increasing/decreasing/shifting?

What is the relation of IR search to other search occasions?

Prior to online what did they do?

Paper only?

(substitutability)

\section{References}

Ackerman, M.S. (1994). Definitional and contextual issues in organizational and group memories. Proceedings of 27th Hawaii International Conference on System Sciences.

Alexander, E.R. (1995). How organizations act together: interorganizational coordination in theory and practice. Amsterdam: Gordon and Breach Publishers.

Alexander, J., \& Scott W.R. (1984). The Impact of regulation on the administrative structure of hospitals: toward an analytic framework. Hospital \& Health Services Administration, May/June:71-85.

Applegate, L.M., McFarlan F.W., \& McKenney J.L. (1996). Corporate information systems management: text and cases, 4th Edition, Chicago, IL: Irwin.

Aumente, J. (1987). New electronic pathways: videotex, teletext and online databases. Newbury Park, CA: Sage.

Baldwin, N.S., \& Rice, R.E. (1997). Information-seeking behavior of securities analysts: individual and institutional influences, information sources and channels, and outcomes. Journal of the American Society for Information Science, 48(8):674-693.

Bell, D. (1973.) The coming of post-industrial society: a venture in social forecasting. New York: Basic Books.
Bellardo, T. (1985). An investigation of online searcher traits and their relationship to search outcome. Journal of the American Society for Information Science, 36(4):241-250.

Berger, P.L., \& Luckman L. (1967). The social construction of reality: a treatise in the sociology of knowledge, New York: Doubleday.

Bijker, W.E. (1995). Of bicycles, bakelites and bulbs: toward a theory of sociotechnical change. Cambridge, MA: The MIT Press.

Bijker, W.E., Hughes T.P., \& Pinch T. (eds.) (1987). The social construction of technological systems, Cambridge, MA: The MIT Press.

Blau, P.M. (1964). Exchange and power in social life. John Wiley \& Sons, Inc. pp.312-15, 327-38. Reprinted in W.M. Evan (Ed.) 1978, Interorganizational Relations. Philadelphia, PA: University of Pennsylvania Press.

Borgman, C.L. (1989). All users of information retrieval systems are not created equal: an exploration of individual differences. Information Processing and Management, 25(3):237-251.

Bowker, G.C., \& Starr S.L. (2001.) sorting things out: classification and its consequences. Cambridge, MA: The MIT Press.

Boyce, B.R., \& Kraft D.H. (1985). Principles and theories in information science. In: Williams, M.E. (Ed.), Annual review of information science and technology, Vol. 20. White Plains, NY: Knowledge Industry Publications. 
Buckland, M.K., \& Liu Z. (1995). History of information science. In M.E. Williams (Ed.), Annual review of information science and technology, Vol. 30. Medford, NJ: Information Today.

Buckley, W. (1967.) Sociology and modern systems theory. Englewood Cliffs, NJ: Prentice-Hall.

Cats-Baril, W.L., \& Jelassi T. (1994). The french videotex system minitel: a successful implementation of a national information technology infrastructure. MIS Quarterly (March), pp. 1-20.

Chee, A. (2000). "Killer apps on the intranet", PRIVATE HREF="http:// www.corporate-intranet.com/treasury/articles/art10.html" MACROBUTTON HtmlResAnchor http://www.corporate-intranet.com/treasury/articles/art10.html (Accessed November, 2000.)

Cooper, M.D. (1983). The structure of the information economy. Information processing and management, 19:9-26.

Covi, L., \& Kling, R. (1996). organizational dimensions of effective digital library use: closed rational and open natural systems models. Journal of the American Society for Information Science, 47(9): 672-689.

Culnan, M.J. (1983). Environmental scanning: the effects of task complexity and source accessibility on information gathering behavior. Decision Sciences, 14(2):194-206.

Culnan, M.J. (1985). The dimensions of perceived accessibility to information: implications for the delivery of information systems and services. Journal of the American Society for Information Science, 36(5): 302-308.

Cyert, R.M., \& March, J.G. (1963). A behavioral theory of the firm. Englewood Cliffs, NJ: Prentice-Hall.

Dervin, B. (1999). On studying information seeking methodologically: the implications of connecting metatheory to method. Information Processing and Management (35), 727-750.

DiMaggio, P.J. (1988). Interest and agency in institutional theory. In: L.G. Zucker (ed), Institutional patterns and organizations, 3-22. Cambridge, MA: Ballinger.

DiMaggio, P.J., \& Powell W.P. (1983). The iron cage revisited: institutional isomorphism and collective rationality in organizational fields. American Sociological Review, 48:147-60.

Dutton, W.H., Kraemer K.L. (1985). Modeling as negotiating. Norwood, NJ: Ablex.

Dutton, W.H., Wyer J., \& O'Connell J. (1993). The governmental impacts of information technology: a case study of Santa Monica's public electronic network. In: Rajiv Banker et al. (Eds.) Strategic information technology management. Harrisburg, PA: Idea Group.

Eng, P.M. (1995). Prodigy is in that awkward stage. Business Week, 3411, February 13, Industrial/Technology Edition:90-91.

Feldman, M.S., \& March, J.G. (1981). Information in organizations as signal and symbol. Administrative Science Quarterly, 26:171-186.

Garvey, W.D. (1979). Communication: the essence of science. New York, NY: Pergamon Press.

Giddens, A. (1984). The constitution of society. Berkeley, CA: University of California Press.

Grudin, J. (1989). Why groupware applications fail: problems in design and evaluation. Office: Technology and People, 4(3):245-264.

Grudin, J. (1993). Interface: an evolving concept. Communications of the ACM, 36(4):110-119.

Guy, M.E. (1985). Professionals in organizations: debunking a myth. New York: Praeger Publishers.

Hall, R.A., Clark J.C., Giordano P.C., Johnson P.V., \& Rockel M.V. (1976). Patterns of interorganizational relationships. American Sociological Review, 36(2):158-169.

Hesse, B.W., Sproull L.S., Kielser S.B., \& Walsh J.P. (1993). Returns to science: computer networks in oceanography. Communications of the ACM, 36(8): 90-101.

Kling, R., \& Iacono S. (1989.) The institutional character of computerized information systems. Office: Technology \& People, v5, n1 (Aug):7-28.

Kling, R., \& McKim G.W. (2000). Not just a matter of time: field differences and the shaping of electronic media in supporting scientific communication. Journal of the American Society for Information Science, 51(14): 1306-1320.
Knorr Cetina, K. (1981.) The manufacture of knowledge: an essay on the constructivist and contextual nature of science. New York, NY: Pergamon Press.

Lamb, R. (1999). Using intranets: preliminary results from a socio-technical field study, Proceedings of 32nd Annual Hawaii International Conference on System Sciences.

Lamb, R. (2001). Tracing influence through intranets of compliance. Proceedings of 34th Annual Hawaii International Conference on System Sciences.

Lamb, R. (2002). Intranet boundaries: social actors and systems integration, Proceedings of 15th Bled Conference on Electronic Commerce, Bled Slovenia, June 17-19, 2002.

Lamb, R., \& Kling R. (In press). Social interaction through information and communication technology: reconceptualizing users. MISQ Special Issue, MIS Workshop Proceedings, Norman, OK, May, 2000.

Larson, M.S. (1977). The rise of professionalism: a sociological analysis. Berkeley and Los Angeles, CA: University of California Press.

Libmann, F. (1990). Study on technology transfer databases. Online Information 90, London, December.

Mack, P.E. (1990). Viewing the earth: the social construction of the Landsat satellite system, Cambridge, MA: MIT Press.

March, J.G., \& Simon H.A. (1958). Organizations. New York, NY: John Wiley \& Sons.

Marchand, D.A., \& Horton F.W. (1986). Infotrends: profiting from your information resources. New York, NY: John Wiley \& Sons, Inc.

Markus, M.L. (1980.) Organizational design and information systems. Unpublished MS, Cambridge, MA: MIT, Sloan School of Management.

Markus, M.L. (1990). Toward a 'critical mass' theory of interactive media. In: Fulk J. \& Steinfield, C.W. (eds), Organizations and communication technology, Newbury Park, CA: Sage.

Miles, M.B., \& Huberman A.M. (1994). An expanded sourcebook: qualitative data analysis, Second Edition. Thousand Oaks, CA: Sage Publications.

Morris, R.C.T. (1994). Toward a user-centered information service. Journal of the American Society for Information Science, 45(1):20-30.

Nardi, B., \& O’Day V. (1999). Information ecologies: using technology with heart. Cambridge: The M.I.T. Press.

Newby, G.B., Nilan, M.S., Duvall L.M. (1991). Toward a reassessment of individual differences in information systems: the power of user-based situational predictors. In: Griffiths J.M. (ed), ASIS '91" Proceedings of the American Society for Information Science (ASIS) 54th Annual Meeting: Volume 28; 1991 October 27-31; Washington D.C.; Medford, NJ: Learned Information; 83-81.

Nicholas, D., Erbach, G., Pang Y. W., \& Paalman K. (1988.) End-users of online information systems: an analysis. New York: Mansell Publishing.

Orlikowski, W.J. (1996). Learning from notes: organizational issues in groupware implementation. In: Kling, R. (ed), Computerization and controversy: value conflicts and social choices, 2nd edition, San Diego, CA: Academic Press.

Orlikowski, W.J., \& Gash D.C. (1994). Technological frames: making sense of information in organizations. ACM Transactions on Information Systems, 12(2), 174-207.

Pettigrew, K.E., \& McKechnie L. (2001). The use of theory in information science research. Journal of the American Society for Information Science, 52(1): 62-73.

Pfaffenberger, B. (1990). Democratizing information: online databases and the rise of end-user searching. Boston, MA: G.K. Hall \& Co.

Pincince, T.J., Goodtree D., \& Barth C. (1996). The Forrester report: network strategies. Forrester Research, Inc.

Porat, M.U., \& Rubin M.R. (1977.) The information economy: definition and measurement. United States Office of Technology Special Publication 77-12(1), Washington: Department of Commerce, Office of Telecommunications.

Porter, M.E., \& Millar, V.E. (1985). How information gives you competitive advantage, Harvard Business Review, July-August, pp.149160. 
Powell, W.W., \& Brantley P. (1992). Competitive cooperation in biotechnology: learning through networks? In N. Nohria \& R.G. Eccles (Eds.), Networks and organizations: structure, form and action, p. 366-394. Boston, MA: Harvard Business School Press.

Powell, W.W., Koput K.W., \& Smith-Doerr L. (1996). Interorganizational collaboration and the locus of innovation: networks of learning in biotechnology. Administrative Science Quarterly, vol. 41, 116-145.

Sage Research, Inc. (1997). Intranet trends second wave, a white paper prepared for CMP Media Inc., Enterprise Computing Group, Spring 1997, (Accessed 1/21/02).

Scott, W.R. (1987). Organizations: rational, natural, and open systems, Second Edition, Englewood Cliffs, NJ: Prentice Hall.

Scott, W.R. (1995.) Institutions and organizations. Thousand Oaks, CA: Sage Publications.

Sproull, L., \& Kiesler, S. (1991). Connections: new ways of working in the networked organization, Cambridge, MA: MIT Press.

Strauss, A., \& Corbin, J. (1990). Basics of qualitative research: grounded theory procedures and techniques. Newbury Park, CA: Sage Publications.

Sugar, W. (1995). User-centered perspective of information retrieval research and analysis methods. In M.E. Williams (Ed.), Annual Review of
Information Science and Technology (ARIST), Volume 30, Medford, NJ: Information Today.

Tolbert, P.S. (1995). Institutional environments and resource dependence: sources of administrative structure in institutions of higher education. Administrative Science Quarterly, 30, 1-13.

Upton, M. (2001). "Portals follow intranets," eBusiness Trends (January 11, 2001), (Accessed 11/4/01).

Wilensky, H.L. (1967). Organizational intelligence. New York, NY: Basic Books.

Williams, M.E. (1985.) Usage of revenue data for the online database industry. Online Review, 9(3):205-210.

Williams, M.E. (1995.) "Highlights of the Online/CDROM database industry: the information industry and the role of the internet. In: Williams, M.E. (Ed.), Proceedings of the Sixteenth National Online Meeting. Medford, NJ: Learned Information.

Wilson, P. (1973). Situational relevance. Information Processing and Management, 9, 475-471.

Wilson, P. (1995). Unused relevant information in research and development. Journal of the American Society for Information Science, 46(1), $45-51$. 